\title{
Conservative oral rehabilitation of the bruxism patient with tooth wear
}

\author{
Min-Gu Kang, Jae-Ho Oh, Kwang-Yeob Song, Ju-Mi Park, Jung-Jin Lee, and Jae-Min Seo* \\ Department of Prosthodontics, School of Dentistry and Institute of Oral Bio-Science, Chonbuk National University, \\ Jeonju 54896, Republic of Korea
}

(Received Aug 22, 2017; Revised version received Sep 11, 2017; Accepted Sep 11, 2017)

\begin{abstract}
Tooth wear, a progressive but gradual loss of convexity on the cusp of the tooth, does not cause premature deterioration of the dentition. However, it may evolve into pathological wear if this normal wear becomes accelerated due to abnormal endogenous or exogenous factors. The pathological wear can lead to pathological changes of pulp, impaired function, occlusal disharmony and aesthetic problems. When treating patients with pathological wear, the cause of the wear must be analyzed, and each tooth should be diagnosed individually. Additionally, the loss of the vertical occlusal dimension, as well as the appropriateness of the space for restoration, should be evaluated. These procedures can prevent the progression of the wear, limit the range of any possible restoration, and finally, allow a clinician to establish a conservative treatment plan. This case report presents a patient with pathological wear caused by bruxism, and treated with monolithic zirconia fixed dental prostheses, so as to restore the lost guidance and the collapsed tooth shape; treatment was made with an occlusal adjustment of specific teeth, which showed interference during lateral excursive movement. As the result of the treatment, the functional movement of the mandible was freed, and the recurrence of tooth wear was prevented. The pathological wear displayed by this patient was successfully treated by this conservative method, as well as a limited range of restoration, all the while ensuring functionality and aesthetically satisfying results.
\end{abstract}

KEY WORDS: Bruxism, Oral rehabilitation, Tooth wear

\section{서 론}

치아마모는 치아 우식, 외상, 발달장애가 아닌 원인들에 의해 발생하는 치아 경조직의 표면상실을 일컫는다[1]. 이 러한 상실은 순수한 생리적 과정이고, 연령증가에 따른 자 연스러운 결과이다[2]. 생리적 마모로 인해 매년 대략 20 38 $\mu \mathrm{m}$ 씩 법랑질의 수직상실이 발생하고[3], 감소한 수 직상실은 치조골의 점진적인 재형성과정을 통한 치조 돌 기의 신장에 의해 보상된다고 알려져 있다[4].

하지만 비정상적인 내적 또는 외적 요인에 의해 발생한 극심하고 가속화된 치질 상실은 병적인 치아마모를 일으 킨다[5]. 한 예로 이갈이는 기계적 치아마모의 내적 요인 이고[6], 비기능적 습관이며 병적인 치아마모를 유발 할

*Corresponding author: Jae-Min Seo

Department of Prosthodontics, School of Dentistry and Institute of Oral Bio-Science, Chonbuk National University, 567 Baekje-daero, Deokjingu, Jeonju 54896, Republic of Korea

Tel.: +82-63-250-2696, Fax: +82-63-250-2218

E-mail: jmseo@jbnu.ac.kr
수 있다[7]. 병적인 치아마모는 치질의 극심한 상실로 치 아민감도증가, 치수손상, 치아변색과 같은 치아자체의 문 제뿐만 아니라 전방유도, 견치유도 및 수직고경의 감소와 같은 기능적 상실을 초래하고 교합 불안정과 심미적인 문 제를 야기한다[8].

Dawson은 치아마모환자 치료 시 명확한 중심위에서 모 든 치아의 균등한 접촉, 측방 운동시 구치부의 즉각적 이 개 등 6 가지 치료지침을 제시하였고, 모든 마모치아의 수 복이 필수는 아니며 교합균형을 통한다면 마모의 원인을 제거할 수 있고, 교합조정은 가장 보존적인 치료법임을 역 설했다[4]. 한편 Turner와 Missirlian은 과도한 마모가 수직 교합고경의 감소를 야기 시킨다는 분명한 증거는 없으며 고경 감소여부에 대한 평가와 수복을 위한 악간 공간의 적 절성 평가가 치료 시 선행 되어야 한다고 보았다. 그는 5 가지 평가항목을 제시하며 고경 상실 여부와 악간 공간 여 부에 기초하여 세 가지 분류법을 언급하였다[9].

본 증례의 환자는 수면 시 이갈이의 비기능적인 습관을 가지고 있으며 상악 일부 치아 및 하악 전치부에 상아질 의 노출을 보이는 증등도 이상의 마모를 보이고 있었다. 
이러한 문제를 가진 환자는 적절한 기능, 심미, 편안함 등 을 얻기 위해 광범위한 수복치료를 필요로 한다[9]. 하지 만 면밀한 진단을 거친 결과, 통상적인 전악 수복을 통하 지 않고 일부 치아들의 교합조정과 보철물만으로도 마모 경향 차단 및 손상된 치질 회복과 동시에 이상적인 교합 형태를 부여할 수 있음을 확인하여 수복범위를 최소화하 고 보존적인 방법으로 치료방향을 설정하였다. 이에 따른 치료 결과 기능적, 심미적으로 만족할 만한 결과를 얻었기 에 본 증례를 보고하고자 한다.

\section{증례보고}

48세 남성 환자로 일부 치아들의 파절과 과도한 마모를 주소로 본원 보철과에 내원하였다. 병력 청취를 통해 수면 시 이갈이 습관을 확인하였고, 구내 검사결과 상악 일부 치아 및 하악 전치부에 상아질의 노출을 보이는 중등도 이 상의 마모와 전측방 운동 시 우측 구치부 균형측 간섭이 관찰되었다. 특히 하악 전치부는 마모면 변연주위로 선각 이 날카롭고 분명한 기계적 마모 양상을 보였다[5](Fig. 1). 파노라마 방사선사진에서 전반적으로 경도의 치주염 증상 을 보이고 \#26,35,45,46 결손, \#25,27 치관 파절 및 우식, \#25,37 치근단 병소를 확인할 수 있었다(Fig. 2). 진단모형 을 제작하고 중심위를 채득한 후 모형을 교합기에 부착하 였다. 수직교합고경의 평가를 위한 다양한 분석을 실시하 였다(Fig. 3). 중절치 절단연과 순측 전정 최저점과의 수직

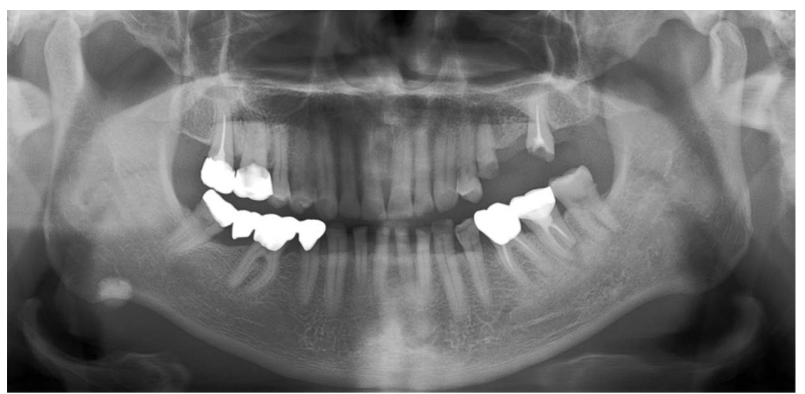

Fig. 2. Pre-treatment panoramic radiograph.

적 거리를 측정한 결과, 상악은 $22 \mathrm{~mm}$, 하악은 $16 \mathrm{~mm}$ 로 Park등의 연구에서 제시한 한국 성인의 평균값과 유사하 였다[10].

전치길이는 상악 $10 \mathrm{~mm}$, 하악 $7 \mathrm{~mm}$ 로 한국 성인 평균 값에서 하악 전치길이가 다소 짧은 것으로 측정되었다 [11]. 그밖에 교합 안정 공극, 전정간 거리, closest speaking space측정 시 정상범위로 측정되었고 [9,10], Willis분석 시 동공간선 구각부 : 비주인중 경계부 턱 끝이 $69 \mathrm{~mm}: 71$ $\mathrm{mm}$ 로 평균치인 $1: 1$ 과 거의 일치하였다[12]. 구외소견으로 안면지지 부족, 얇은 입술, 축 처진 구각부, 구순증 등이 관찰되지 않았고, 평균의 naso-labial angle (mean: 93.9 97.3') 을 보였다[13]. 진단모형에서 우측 구치부는 마모 및 파절 소견 없으며, 안정적인 vertical stop이 존재하였다. 이상의 결과에서 환자의 수직고경은 상실되지 않음을 알 수 있었 다. 이후 수복을 위한 악간 공간의 적절성 여부 판단을 위 해 진단모형에 수직고경 증가 없이 진단납형을 형성하였

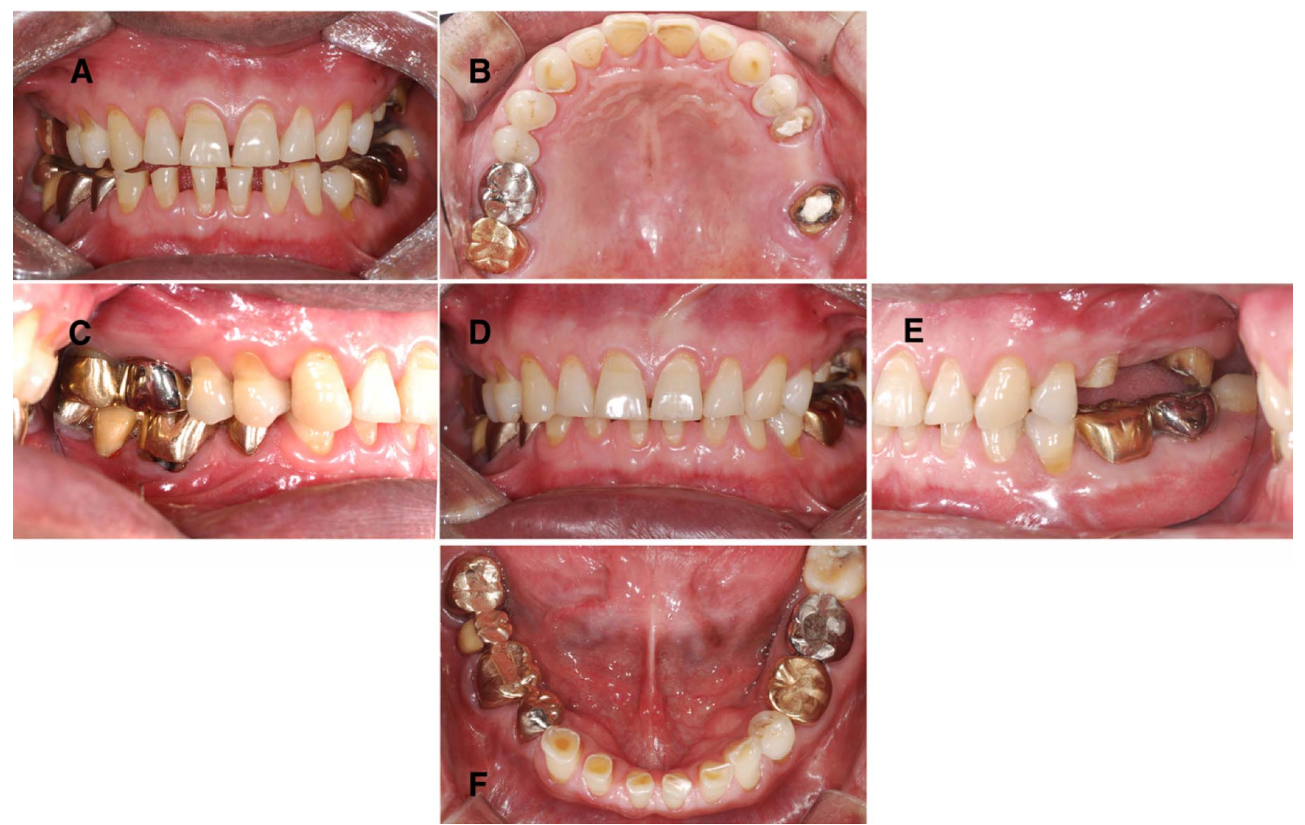

Fig. 1. Pre-treatment state. (A) Mandibular anterior movement: checking the interference of the right posterior teeth, (B) Maxillary occlusal view, (C) Right lateral view, (D) Frontal view, (E) Left lateral view, (F) Mandibular occlusal view: verifying the distinctive mechanical wear characteristics of wear facets with sharply defined line angles on the anterior teeth. 
Min-Gu Kang et al.
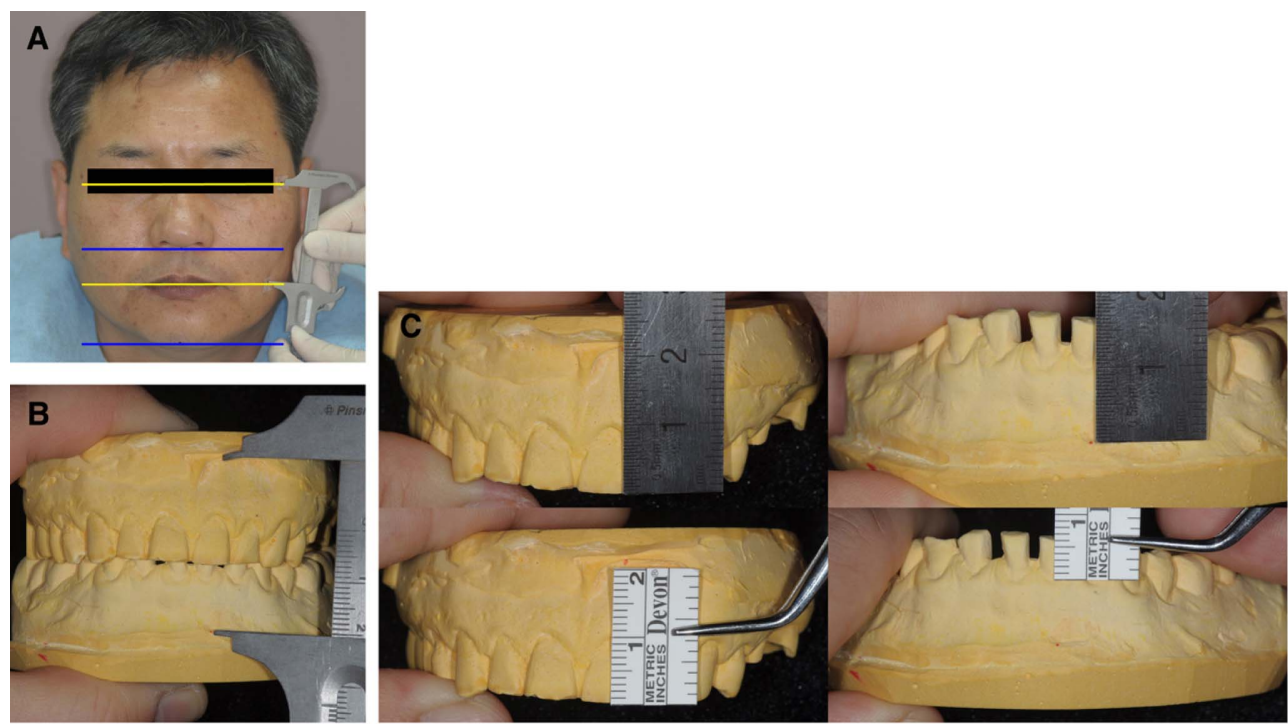

Fig. 3. Vertical dimension evaluation. (A) Facial evaluation using Willis method: comparing the distance from the bony shelf under the nose to the bottom of the mandible and from the pupil of the eyes to the rima oris, (B) Inter-vestibular distance: measuring the vertical distance between both bottoms of labial vestibules on maxillary and mandibular casts, (C) Analysis on the degree of teeth attrition: measuring the vertical distance from the incisal edge of central incisor to the bottom of labial vestibule and the tooth length of the central incisor on maxillary and mandibular casts.
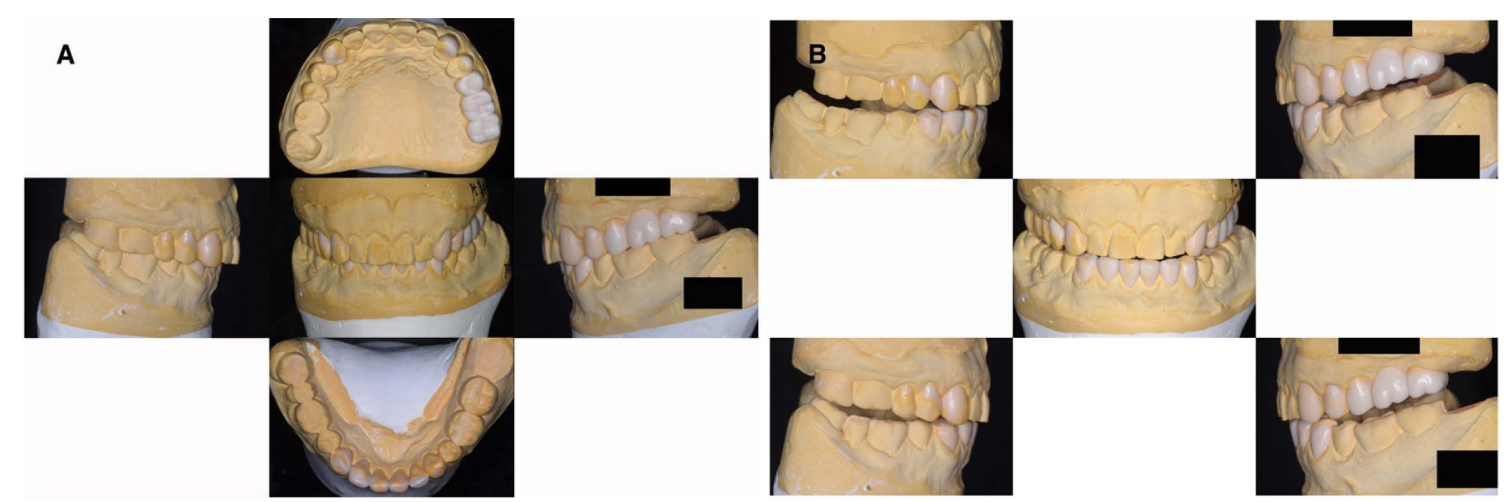

Fig. 4. Diagnostic wax-up model. (A) Maximum intercuspation: checking the firm contact of all teeth, (B) Excursive movement of mandibular cast: confirming the posterior teeth disocclusion during function.

다. 납형 형성 결과, 보철물을 위한 충분한 공간이 확인되 었으며, 최대교두감합위에서 모든 치아들의 확실한 유지 접촉과 모든 하악 운동에서 전치 및 견치유도가 구치를 이 개 시킬 수 있음을 확인하였다(Fig. 4). 이를 통해, 본 증례 는 수직고경 상실 없이 가용한 보철물 수복공간이 남아있 는 과도한 마모증례로 Turner와 Missirlian의 category No. 2로 판단할 수 있었다[9].

치과보존과 및 치주과와의 협진을 통해 \#25,37 근관치 료, 치주염 치료 및 유지관리를 시행하였다. 본 과에서는 교합조정을 통해 \#17과 47간의 편심측 간섭을 제거하고, \#26 임플란트 식립 및 \#38 발치를 시행하며 중등도 이상 의 마모를 보이는 \#14,13,23,24 그리고 하악 6 전치와 파 절된 \#27, 근관치료 완료된 \#25,37 의 보철수복을 통해 견
치유도를 포함한 상호 보호 교합을 부여하고 이갈이로부 터 치질 및 주위조직, 보철물을 보호하기 위한 야간 보호 장치를 장착하기로 치료계획을 수립하였다.

초기 치아삭제 후, 편심 운동 시 간섭이 없도록 진단납 형을 재현한 임시 보철물을 합착하였다. 기존의 수직교합 고경을 유지하면서 좌, 우 측방 운동 시 양측 견치 유도 부여하였고, 교합조정을 실시하여 \#17과 47간의 균형측 간섭을 제거하였다(Fig. 5).

그 후 \#26 (4.8*11 mm, Straumann Roxolid SLActive BLT®, Basel, Switzerland) 임플란트를 식립하였다. 임플란트 수술 1 개월 뒤 Implant stability quotient (ISQ: 83)값 측정하여 골유착 안정성 확인하였고[14], \#26 임플란트 임시보철물 제작 시 최대교두감합위와 편심 운동 중 특정치아의 간섭 

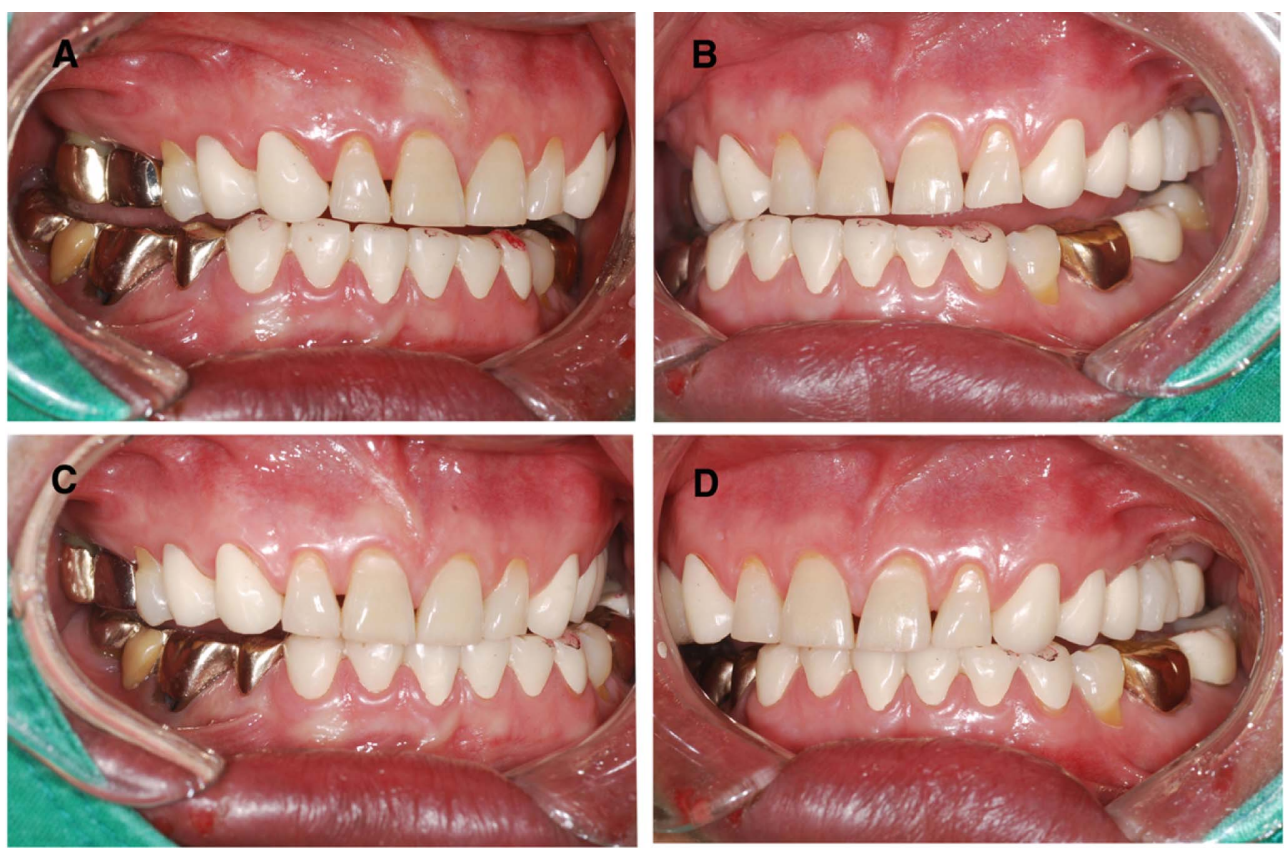

Fig. 5. Provisional restoration setting - lateral excursive movement. (A) Right movement, working side, (B) Right movement, non-working side, (C) Left movement, non- working side, (D) Left movement, working side.
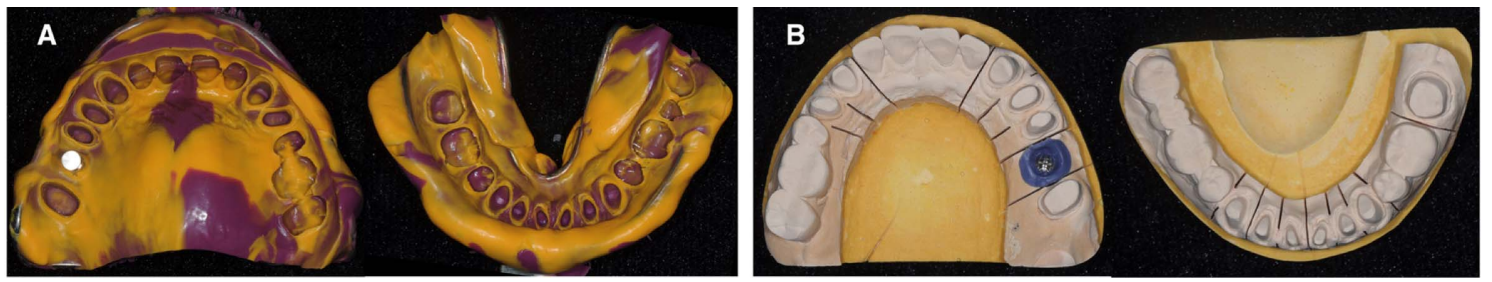

Fig. 6. Master cast fabrication. (A) Final impression, (B) Working model for fixed prostheses.
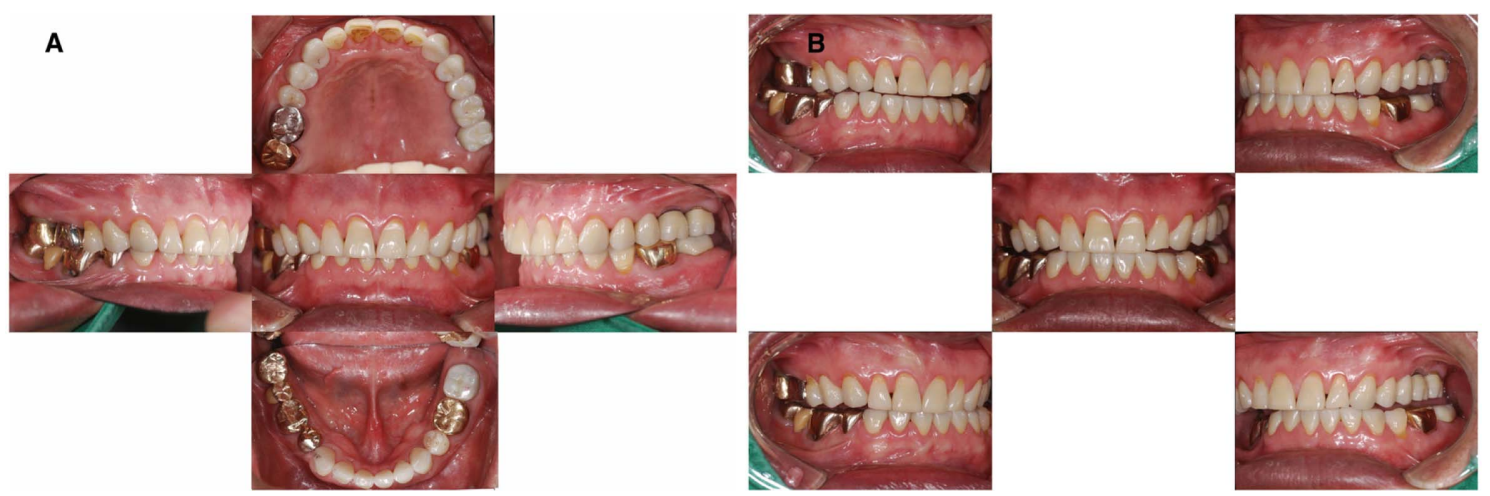

Fig. 7. Final fixed prostheses setting. (A) Maximum intercuspation: checking the firm contact of all teeth, (B) Excursive movement of mandible: confirming the posterior teeth disocclusion during function.

없음을 재확인하였다. 이후 임시보철물 사용 4 개월 동안 악관절의 이상소견 유무, 교합안정성, 심미, 통증 등을 평 가하여 특이소견 없어 최종보철물을 제작하기로 하였다.

부가중합형 실리콘 인상재(Aquasil Ultra XLV, Monophase, Dentsply Caulk, Milford, USA)를 이용하여 임플란트를 포 함한 모든 지대치의 최종 인상을 채득하고 작업 모형을 제
작하였다(Fig. 6). 임시보철물 장착상태에서 안궁이전을 시 행하고 모형을 제작하여 개인 맞춤형 절치유도판을 제작 하였다. 악간관계를 채득하고 임시보철물 모형과 cross mounting하여 작업모형을 교합기에 부착 후, 최종 보철물 을 제작하였다. \#14,13,23 25,27,33 43,37 자연치 및 \#26 임플란트 상부보철은 심미성보다는 보철물의 강도 및 내 

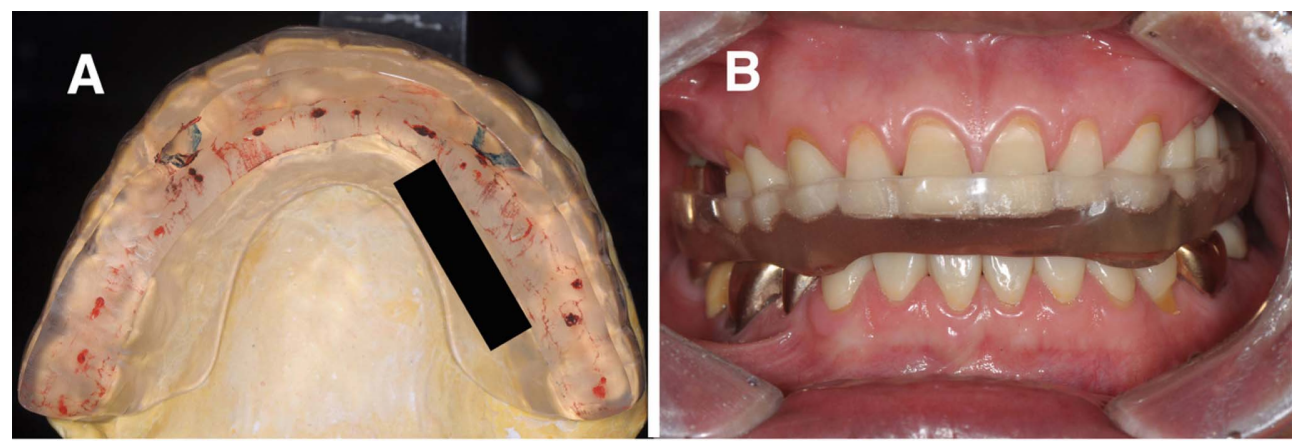

Fig. 8. Night guard. (A) Occlusal view: checking uniform, equal-intensity contacts against all mandibular teeth on the night guard surface in occlusion when the joints are completely seated in centric relation, (B) Frontal view: guidance ramps on both canines of maxilla provide immediate disocclusion of all mandibular teeth except canines in all excursive jaw movements from centric relation.

구성[15]과 대합치 마모[16]를 우선적으로 고려하여 모두 단일구조 지르코니아(Upcera Zirconia Block, Liaoning Upcera Co., Guangdong, China) 보철물로 제작하였다. 상, 하악 지대치 및 임플란트 맞춤형 지대주(MIT®, Doowon Co., Seoul, Korea)에 지르코니아 최종 보철물을 시적, 교 합조정 후 최대교두감합위에서 안정적인 교합접촉 및 편 심 운동 시 상악 전치 및 견치의 안정적인 하악 유도를 확 인하였다(Fig. 7). 보철물은 내면을 tribochemical silica coating (Rocatec, 3M ESPE, Seefeld, Germany)과 silane coupling agent (RelyX Ceramic Primer, 3M ESPE, St. Paul, $\mathrm{MN}, \mathrm{USA}$ ) 처리하고, adhesive (Single Bond Universal, 3M ESPE)를 얇게 펴 바른 후 이중 중합형 레진시멘트(RelyX Ultimate, 3M ESPE)로 합착하였다.

최종 보철물 합착 이후, 견치유도를 부여한 야간 보호 장치를 제작하여 취침 시에 장착하도록 하였다(Fig. 8). 최 종 합착 1 주, 3 개월, 6 개월 후에 교합분석장비(T scan III, Tekscan Inc, Boston, MA, USA)를 이용하여 최대교두감합

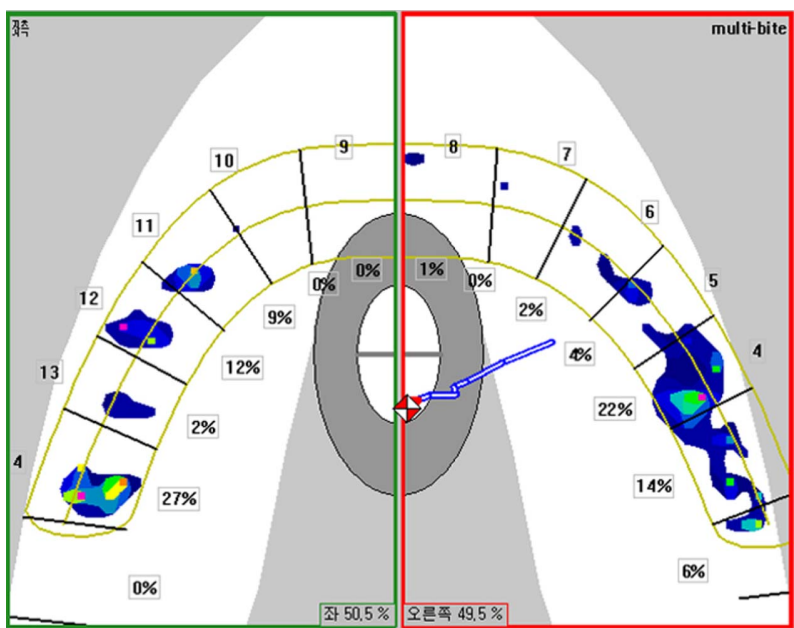

Fig. 9. Occlusal analysis using T scan III: checking evenly distributed occlusal force.

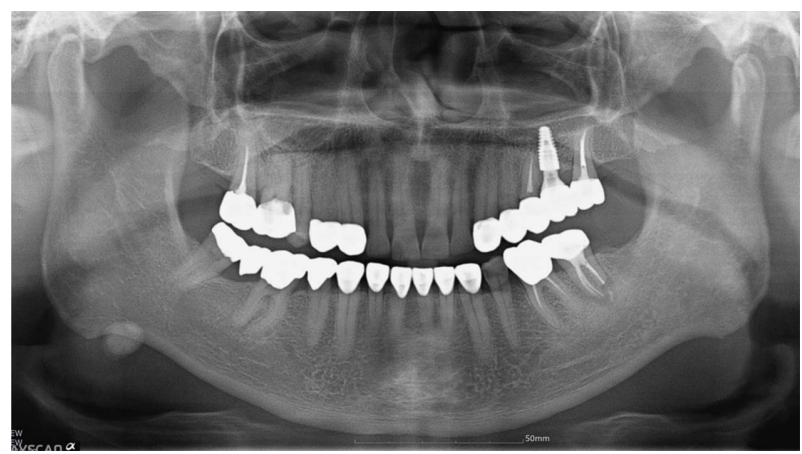

Fig. 10. 18months post-treatment panoramic radiograph.

시 균등한 교합력 분산과 안정적인 구치부 교합을 확인하 였고(Fig. 9), 전방 운동 시 \#11,21 에 의해 구치가 즉시 이 개 되고 측방 운동 시 견치유도교합이 형성됨을 확인하였 다. 바른 구강위생관리방법, 식이 조절, 그리고 야간 보호 장치 사용에 대한 교육을 통해 치아 마모가 재발되지 않도 록 노력하였다. 최종 보철물 장착 1년 6 개월 동안 경과 관찰 결과, 특별한 문제 발생 없이 환자와 술자 모두 심미적, 기 능적으로 만족할 만한 결과를 얻을 수 있었다(Fig. 10).

\section{고 찰}

치아마모의 기전으로 알려진 attrition, abrasion, erosion, abfraction은 독립적으로 작용할 수도 있지만 대개 역동적 인 교합활동 동안 둘 이상의 기전이 연합하여 마모를 일 으킨다[6]. 이러한 연합된 기전 때문에 임상가들은 치아마 모환자에 대한 원인요소를 밝히고 명확한 진단을 내리는 데 어려움을 겪는다. 이를 위해 Verrett는 마모된 치아의 외형 등을 통해 원인을 파악할 수 있도록 하였고[5], Donachie와 Walls는 연령을 고려하여 법랑질의 수준, 상아 질의 노출 정도, 그리고 치경부의 결손 깊이를 평가하는 수정된 tooth wear index (TWI)를 제시하였다[17]. 
본 증례의 환자는 식이를 포함한 생활 습관과 이갈이의 구강 악습관이 복합적으로 작용하여 치아의 기계적 마모 가 발생한 경우로[6], 동일연령대의 TWI에 비추어봤을 때 하악 6전치와 \#14,13,23,24 에 병적 치아마모가 일어났다 고 판단할 수 있었다[17]. 그리고 이러한 병적인 치질의 상 실로 인하여 발생한 전치유도의 상실이 연쇄적으로 치아 마모를 더욱 가속화시켰다고 볼 수 있다. 그러나 병력 및 구치부 지지, 발음, 교합면 간 거리 및 안모, inter-vestibular distance등의 구외 및 진단 모형을 통한 평가 시 수직교합 고경의 감소가 없다고 사료되었다[9,10]. 따라서 현재 수직 교합고경에서 진단납형제작을 통해 이상적인 교합을 부여 할 수 있고 마모된 치아를 회복시킬 수 있는 보철물을 위 한 악간 공간을 평가하였다. 평가 결과, 보철물을 위한 공 간이 확보 가능할 것으로 판단되어 현재의 수직교합고경 을 유지한 상태에서 보철치료계획을 수립하였다.

치아마모 환자에게 마모예방목적으로 마모치아뿐만 아 니라 주변의 건전한 치아까지 치료범위를 확대하여 다수 의 단관과 가공의치를 이용한 수복은 치질에 파괴적인 악 영향을 미칠 수 있다[18]. 따라서 수복방법과 재료를 결정 함에 있어 보다 보존적 방법으로 수복하는 것이 권장되고 있다[19]. 이러한 보존적 수복법은 치질 보존, 비용 효율적, 그리고 시간 절약적인 장점이 있다[20]. 본 증례는 교합조 정을 통해 편심위 교합간섭을 제거하고 심한 상아질의 노 출이 있는 치아들만의 수복으로 이상적인 교합양식을 부 여할 수 있음을 보인 증례로 치료 범위를 국소화시키더라 도 마모의 진행을 충분히 막을 수 있었다[4].

수복 재료선택 시 심미성보다는 환자의 이갈이 습관을 고려하여 단일구조 지르코니아를 수복재료로 사용하였다. Tinschert등은 core ceramics의 파절강도를 측정하는 연구 에서 Lithium Disilicate 및 Alumina와 같은 전통적인 세라 믹 재료를 이용한 고정성 보철물 보다 지르코니아를 이용 한 고정성 보철물의 파절강도가 3 배정도 높게 측정됨을 보고하였다[15]. 또한 $\mathrm{Kim}$ 등은 자연치와 대합하는 재료를 달리하여 마모도를 평가하는 연구에서 Lithium Disilicate 와 feldspathic porcelain에 의한 자연치 마모 정도가 지르 코니아에 의한 자연치 마모 정도보다 유의하게 높음을 보 고 하였다[16]. 이러한 지르코니아를 수복재료로 선택하여 기존의 전부 도재관보다 더 큰 강도와 큰 파절 저항성을 확보하고, 대합치 마모를 줄이려고 하였다.

\section{결 론}

병적인 치아마모를 보이는 환자에게 마모의 원인분석 및 해결, 개별치아의 진단, 그리고 교합조정 등은 치료 범 위를 국소화하며 최소침습적인 완전 구강회복을 가능하게
하고, 마모의 재발방지에 도움이 된다. 더불어 단일 구조 지 르코니아는 이를 위한 고정성 보철재료로 추천할만하다.

\section{Conflict of Interest}

The authors declare that they have no competing interests.

\section{ORCID}

$\begin{array}{ll}\text { Min-Gu Kang } & 0000-0002-8981-200 X \\ \text { Jae-Ho Oh } & 0000-0002-4298-1965 \\ \text { Kwang-Yeob Song } & 0000-0003-4283-1278 \\ \text { Ju-Mi Park } & 0000-0003-1910-1525 \\ \text { Jung-Jin Lee } & 0000-0002-7381-5230 \\ \text { Jae-Min Seo } & 0000-0001-5095-4046\end{array}$

\section{References}

1. Mehta SB, Banerji S, Millar BJ, Suarez-Feito JM. Current concepts on the management of tooth wear: part 1 . Assessment, treatment planning and strategies for the prevention and the passive management of tooth wear. Br Dent J 2012;212:17-27. doi: 10.1038/sj.bdj.2011.1099.

2. Flint S, Scully C. Orofacial age changes and related disease. Dent Update 1988;15:337-342.

3. Lambrechts P, Braem M, Vuylsteke-Wauters M, Vanherle G. Quantitative in vivo wear of human enamel. J Dent Res 1989;68:1752-1754. doi: 10.1177/00220345890680120601.

4. Dawson PE. Functional occlusal : from TMJ to smile design. St. Louis: Mosby; 2007.

5. Verrett RG. Analyzing the etiology of an extremely worn dentition. J Prosthodont 2001;10:224-233. doi: 10.1111/ j.1532-849X.2001.00224.X.

6. Grippo JO, Simring M, Schreiner S. Attrition, abrasion, corrosion and abfraction revisited: a new perspective on tooth surface lesions. J Am Dent Assoc 2004;135:11091118. doi: 10.14219/jada.archive.2004.0369. Erratum in: J Am Dent Assoc 2004;135:1376.

7. Reddy SV, Kumar MP, Sravanthi D, Mohsin AH, Anuhya V. Bruxism: A Literature Review. J Int Oral Health 2014; 6:105-109.

8. Muts EJ, van Pelt H, Edelhoff D, Krejci I, Cune M. Tooth wear: A systematic review of treatment options. J Prosthet Dent 2014;112:752-759. doi: 10.1016/j.prosdent.2014.01.018.

9. Turner KA, Missirlian DM. Restoration of the extremely worn dentition. J Prosthet Dent 1984;52:467-474. doi: 
10.1016/0022-3913(84)90326-3.

10. Park JH, Jeong CM, Jeon YC, Lim JS. A study on the occlusal plane and the vertical dimension in Korean adults with natural dentition. J Korean Acad Prosthodont 2005;43:41-51.

11. Kwon KR. The prosthetic approach for collapsed vertical dimensions of occlusion. Journal of dental rehabilitation and applied science 2004;20:169-181.

12. Willis FM. Features of the face involved in full denture prosthesis. Dent Cosmos 1935;77:851-854.

13. Brown M, Guyuron B. Redefining the ideal nasolabial angle: Part 2. Expert analysis. Plast Reconstr Surg 2013; 132:221e-225e. doi: 10.1097/PRS.0b013e3182958b40.

14. Rodrigo D, Aracil L, Martin C, Sanz M. Diagnosis of implant stability and its impact on implant survival: a prospective case series study. Clin Oral Implants Res 2010;21:255-261. doi: 10.1111/j.1600-0501.2009.01820.x.

15. Tinschert J, Natt G, Mautsch W, Augthun M, Spiekermann H. Fracture Resistance of Lithium Disilicate-, Alumina-, and Zirconia-Based Three-Unit Fixed Partial Dentures: A Laboratory Study. Int J Prosthodont 2001; 14:231-238.
16. Kim MJ, Oh SH, Ju SW, Seo DG, Jun SH, Ahn JS, Ryu JJ. Wear evaluation of the human enamel opposing different Y-TZP dental ceramics and other porcelains. J Dent 2012;40:979-988. doi: 10.1016/j.jdent.2012.08.004.

17. Donachie MA, Walls AW. The tooth wear index: a flawed epidemiological tool in an ageing population group. Community Dent Oral Epidemiol 1996;24:152-158. doi: 10.1111/j.1600-0528.1996.tb00833.x.

18. Burke FJ, Kelleher MG, Wilson N, Bishop K. Introducing the concept of pragmatic esthetics, with Special Reference to the Treatment of Tooth Wear. J Esthet Restor Dent 2011;23:277-293. doi: 10.1111/j.1708-8240.2011.00462.x.

19. Mehta SB, Banerji S, Millar BJ, Suarez-Feito M. Current concepts on the management of tooth wear: part 4. An overview of the restorative techniques and dental materials commonly applied for the management of tooth wear. Br Dent J 2012;212:169-177. doi: 10.1038/sj.bdj. 2012.137.

20. Meyers IA. Diagnosis and Management of the Worn Dentition: Conservative Restorative Options. Ann R Australas Coll Dent Surg 2008;19:31-34. 